\title{
Assessment of the quality of drinking water in storage tanks and its implication on the safety of urban water supply in developing countries
}

\author{
Derara Chalchisa, Moa Megersa ${ }^{*}$ and Abebe Beyene
}

\begin{abstract}
Background: Water quality problems are one of the manifestations of poverty and most developing countries including Ethiopia suffering a lot of health problems associated with consumption of contaminated water. Although communities living in urban areas of Ethiopia have access to piped water supply, cross-contamination in the distribution system and unsafe storage are the major source of water borne diseases hence they are mostly overlooked by water professionals.

Results: All water samples collected from drinking water storage tanks were positive for total coliforms and faecal coliforms. The result of this study showed that the drinking water was microbially contaminated in all sampling points. The level of microbial contamination increased from before entering the storage tank to after leaving the storage tank indicating that the presence of leakage in the distribution system and contamination at the storage tanks. The turbidity was found in the safe water quality range (2.1-2.9 NTU).

Conclusion: The current study indicated that all water samples were bacteriologically contaminated and none of them met the WHO maximum permissible limit of drinking water quality. The unsafe piped-water supply was attributed to both leakage and contamination in the distribution system or unsafe storage. Thus, detail risk assessment should be conducted from treatment to distribution including storage and safe handling of water at the point of use in order to provide complete intervention strategies in tackling waterborne diseases.
\end{abstract}

Keywords: Drinking water, Safe water, Water storage

\section{Background}

Water use has been growing at more than the rate twice of population increase in the last century. The world's six billion people are appropriating $54 \%$ of all the accessible freshwater contained in rivers, lakes and underground aquifers (WWAP 2012). The available fresh waters are being polluted by anthropogenic factors and are reducing the availability of potable water (Fard et al. 2012). Water quality is becoming a major problem, as evidenced by frequent outbreaks of water borne diseases in both

\footnotetext{
*Correspondence: moamegersa78@gmail.com

Department of Environmental Health Science and Technology, Jimma University, P.O. Box 378, Jimma, Ethiopia
}

rural and urban areas of developing countries. Water borne diseases are still a major health burden in many parts of the world and estimated to cause about 842,000 diarrhoea disease deaths per year (WHO 2014). At present, 663 million people do not have access to clean and safe water out of which $37 \%$ of those people live in Sub-Saharan Africa (UNICEF/WHO 2015). Safe drinking water is defined as water with microbial, chemical and physical characteristics that meet WHO guidelines (WHO 2015). For instance, the microbial guideline states that coliform bacteria must not be detectable in $100 \mathrm{ml}$ samples of water to be considered as safe and their presence in drinking water indicates the possibility of pathogenic bacteria. Regarding the physicochemical quality of 
drinking water, the guidelines states that water with turbidity values below 5 NTU can be considered as safe, in these terms of turbidity.

Ethiopia is one among the lowest to have accessible quality water supply in Sub-Saharan Africa (UNICEF/ WHO 2015). However, the country has halved the number of people without access to safe water since 1990 . Despite the remarkable progress seen in Ethiopia, more than 48 million people do not have access to improved water source and the majority of health facilities in the country lack access to clean water (UNICEF/WHO 2015). Even for those people who have access to clean water, the provision is irregular or insufficient where piped water supply operates sporadically. Therefore, storage tanks are commonly used to ensure that there is sufficient water for short or long term usage. Water storage tanks have their own impact on quality of water if they are not handled in hygienic ways such as using of clean utensils and sealing or covering of the storage tanks. Common problems in storage tanks and reservoirs are the loss of disinfectant residual, bacteria re-growth, poor turnover, and excessive detention time (Duer 2006). There are various reports on the re-growth of bacteria in water stored during a short or long time. For instance, Akuffo et al. (2013) recorded up to $250 \mathrm{cfu} / 100 \mathrm{ml}$ of FC from water storage tanks found in Ghana. The water stored for 1-9 days showed $67 \%$ of increased contamination which could be the reason for increment of coliforms as storage time increased (Brick et al. 2004).

In Ethiopia, the discontinuity of drinking water supply, hinders the distribution of water to people in need. This discontinuity creates a need to use storage tanks. Likewise, in Jimma, irregular provision of piped water is frequently observed and presence of water storage tanks is vital. Small to large sized plastic water storage tanks commonly called 'Rotto' are found and used as water storage containers. Water stored in unhygienic manner may be re-contaminated, and can cause water borne diseases. Contamination most often occurs with deteriorated infrastructure; allowing entry of particulate or other nonpotable material. Therefore, the main objective of this study was to assess physicochemical and bacteriological qualities of tap water stored in water storage tanks.

\section{Methods}

\section{Study area}

The study was conducted in Jimma town, which is found in Jimma Zone, Oromia, south-west of Ethiopia (Fig. 1). Geographically, Jimma town is located between $7^{\circ} 40^{\prime} \mathrm{N}$ latitudes, $36^{\circ} 50^{\prime} \mathrm{E}$ longitude and an average altitude of about 1780 above sea level. The study area is categorized in the climatic zone locally known as Woina Dega (subtropical zone). It is characterized by warm climate with a

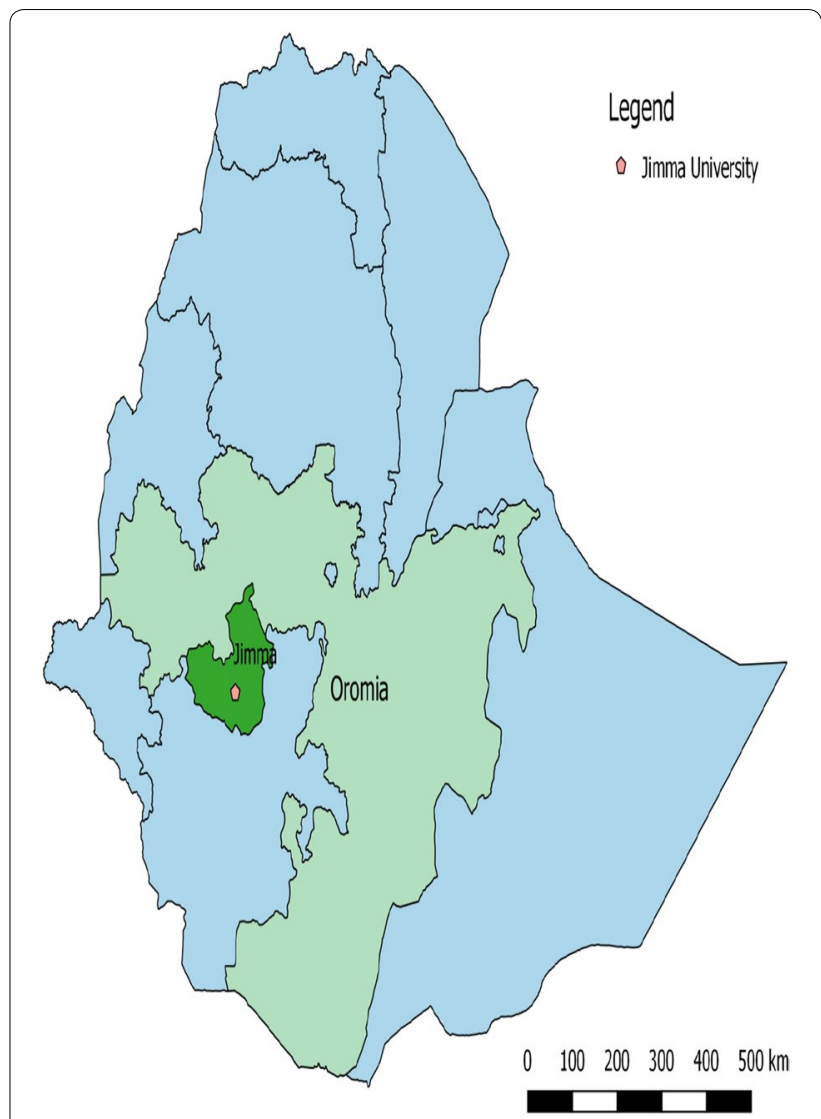

Fig. 1 Map of the study area

mean annual maximum temperature of $30{ }^{\circ} \mathrm{C}$ and a mean annual minimum temperature of $14{ }^{\circ} \mathrm{C}$ (Alemu et al. 2011). The annual rainfall ranges from 1138 to $1690 \mathrm{~mm}$. Jimma University, one of the leading national universities is found in the town and it educates more than 43,000 students yearly.

The study was conducted on piped-water supply before entering the storage tanks and after leaving the water storage tanks which are found in Jimma. Nineteen water storage tanks were analyzed but the finding from six of water storage tanks presented in this study as most of the tanks were interconnected and the water is delivered with single pipe line. The tanks are made up of plastic material and commonly called 'Rotto'. The water storing capacity of the tanks ranged from 2500 to $25,000 \mathrm{~L}$ and were filled with tap water.

\section{Water sample collection and transportation}

All water samples from storage tanks were collected using clean and sterile polyethylene plastic bottles. The samples were stored in an ice box and transported to the environmental health science and technology laboratory of Jimma University, Ethiopia for analysis. Temperature 
was directly measured but other parameters were tested within $6 \mathrm{~h}$ of collection.

\section{Physicochemical analysis}

The collected water samples were taken using a pipette from the middle of the beaker for analysis of physicochemical parameters $(\mathrm{pH}$ and turbidity). The turbidity for each of the water samples collected from water storage tanks was measured using a turbidity meter (Oakton $\mathrm{T}$-100). The $\mathrm{pH}$ and temperature were measured using multi-parameter probe $(\mathrm{HACH})$. For a $\mathrm{pH}$ measurement, the equipment was first standardized with a buffer solution of $\mathrm{pH}$ ranging from 4 to 9 . All tests were performed in triplicates and the averages are reported herein.

\section{Bacteriological analysis}

Water samples collected from the storage tanks were plated aseptically onto MacConkey agar for total coliforms and faecal coliforms following the standard protocols as described by Cheesbrough (2006). Incubation was carried out at $37^{\circ} \mathrm{C}$ for $24 \mathrm{~h}$ for total coliforms and $44.5{ }^{\circ} \mathrm{C}$ for $24 \mathrm{~h}$ for faecal coliforms and count was carried out following the standard microbiological procedures by APHA (2005).

\section{Data analysis}

The collected data were entered into Excel spreadsheet 2007 and summarized using table, percentages and mean. Additionally, the Pearson correlation coefficient and $t$ test were used to analyze the association between various drinking water parameters and detect significant variations among biological parameters in different water storage tanks to determine the difference between before and after storing water.

\section{Results}

\section{Bacteriological test of drinking water quality in storage} tanks

All water samples collected from drinking water storage tanks were positive for TC and FC (Table 1). The TC counts ranged from 2.6 to 14.3 whereas, the FC counts ranged from 1.3 to $9.33 \mathrm{cfu} / 100 \mathrm{ml}$.

\section{Physicochemical analysis}

The $\mathrm{pH}$ of the storage water from different sources ranged from 7.13 to 7.41 and the recorded temperature of the water samples ranged from 21.3 to 23.1 (Table 2). The turbidity value of water samples was ranged from 2.08 to 2.93 .

\section{Correlation of collected water sample parameters}

The correlation analysis indicated the positive association between various water samples parameters (Table 3).
Table 1 Mean bacterial count of water samples stored in storage tanks

\begin{tabular}{llllll}
\hline Storage tanks & \multicolumn{2}{l}{ TC cfu/100 $\mathbf{~ m l}$} & & \multicolumn{2}{l}{ FC cfu/100 $\mathbf{~ m l ~}$} \\
\cline { 2 - 3 } \cline { 5 - 6 } & $\begin{array}{l}\text { Before } \\
\text { storage }\end{array}$ & $\begin{array}{l}\text { After } \\
\text { storage }\end{array}$ & & $\begin{array}{l}\text { Before } \\
\text { storage }\end{array}$ & $\begin{array}{l}\text { After } \\
\text { storage }\end{array}$ \\
\hline B & 2.6 & 4 & & 1.3 & 4.6 \\
AJ 1 & 8.33 & 8.36 & & 6.33 & 7.66 \\
AJ 2 & 8.33 & 14.33 & & 6.33 & 9.33 \\
AJ 3 & 8.33 & 12 & & 6.33 & 7.33 \\
Gate 4 A & 5.66 & 7.33 & & 4.6 & 7 \\
Gate 4 B & 5.66 & 10.6 & & 4.6 & 7.33 \\
\hline
\end{tabular}

Most importantly, very strong positive relationship was observed between $\mathrm{pH}$ and bacterial counts before and after water storage. No association was observed between temperature and turbidity.

\section{Comparison of bacteriological contamination of water before and after storage}

The comparison between bacteriological contamination of drinking water among samples taken from water tanks before and after storage showed that the bacteriological contamination of water with total coliforms is higher than the contamination with faecal coliforms. The result also revealed that the number of total coliforms increased after storage. However, the difference was statistically insignificance $(p=0.06)$. In the case of faecal coliforms, statistically significant result $(p=0.02)$ was observed between the numbers before and after storage.

\section{Sanitary conditions of water storage tanks}

Unhygienic way of storing water was exhibited in water storage tanks. Leakage of valve seals was the leading responsible for the reported poor water quality in terms of coliforms. Out of the 19 studied water storage tanks, leakage of valve seal was observed in 13 of the tanks (66.6\%) (Fig. 2).

\section{Discussion}

People think that piped water have a high quality, though it can be potentially deteriorated (biological and chemical) in distribution systems (AWWA 2007). Many microbial and chemical constituents of drinking water can potentially cause adverse human health effects (WHO 2006). Water storage tanks and reservoirs are critical component of distribution systems, yet can pose significant challenge for water utilities as they often have a negative impact on water quality. In the present study, total coliforms and faecal coliforms are considered as they are indicators of sanitary quality of water and 
Table 2 Physicochemical quality of water samples stored in storage tanks

\begin{tabular}{|c|c|c|c|c|c|c|}
\hline \multirow[t]{2}{*}{ Storage tanks } & \multicolumn{2}{|l|}{ Turbidity } & \multicolumn{2}{|l|}{$\mathrm{pH}$} & \multicolumn{2}{|l|}{ Temperature } \\
\hline & Before storage & After storage & Before storage & After storage & Before storage & After storage \\
\hline B & 2.08 & 2.42 & 7.13 & 7.14 & 21.33 & 21.36 \\
\hline AJ 1 & 2.63 & 2.54 & 7.40 & 7.26 & 22.2 & 23 \\
\hline$A J 2$ & 2.63 & 2.65 & 7.40 & 7.41 & 22.2 & 23 \\
\hline AJ 3 & 2.63 & 2.7 & 7.40 & 7.36 & 22.2 & 23.1 \\
\hline Gate 4 A & 2.79 & 2.84 & 7.31 & 7.29 & 21.53 & 21.9 \\
\hline Gate 4 B & 2.79 & 2.93 & 7.31 & 7.34 & 21.53 & 22 \\
\hline
\end{tabular}

Table 3 Correlation coefficients among water quality parameters before and after storage

\begin{tabular}{llllll}
\hline Parameters & Turbidity & $\mathbf{p H}$ & Temperature & TC & FC \\
\hline Turbidity & 1.00 & & & & \\
pH & 0.74 & 1.00 & & & \\
Temperature & 0.33 & 0.87 & 1.00 & 1.00 & \\
TC & 0.61 & 0.98 & 0.94 & 0.98 & 1.00 \\
FC & 0.73 & 0.99 & 0.88 & & \\
After storage & & & & & \\
Turbidity & 1.00 & & & & \\
pH & 0.60 & 1.00 & & 1.00 & \\
Temperature & 0.00 & 0.68 & 1.00 & 0.89 & 1.00 \\
TC & 0.41 & 0.96 & 0.76 & & \\
FC & 0.38 & 0.90 & 0.78 & & \\
\hline
\end{tabular}

pathogenic bacteria. The presence of colonies in drinking water before and after storage may show that the water either contaminated during distribution or the treatment process was not sufficient to eliminate microorganisms. This is a problem in developing countries where microbial contamination of protected drinking water is wide spread. The term "protected water" made international estimates to greatly overstate access to safe drinking water and call for enhanced monitoring strategy combining indicators of sanitary protection with measures of water quality (Bain et al. 2014).

For instance, Zaqoot et al. (2016) recorded low to high total coliforms $(1-100 \mathrm{cfu} / 100 \mathrm{ml})$ from tap water stored in storage tanks found in Palestine. Similarly, drinking water samples collected from different protected

\section{Condition of water storage tanks (\%)}

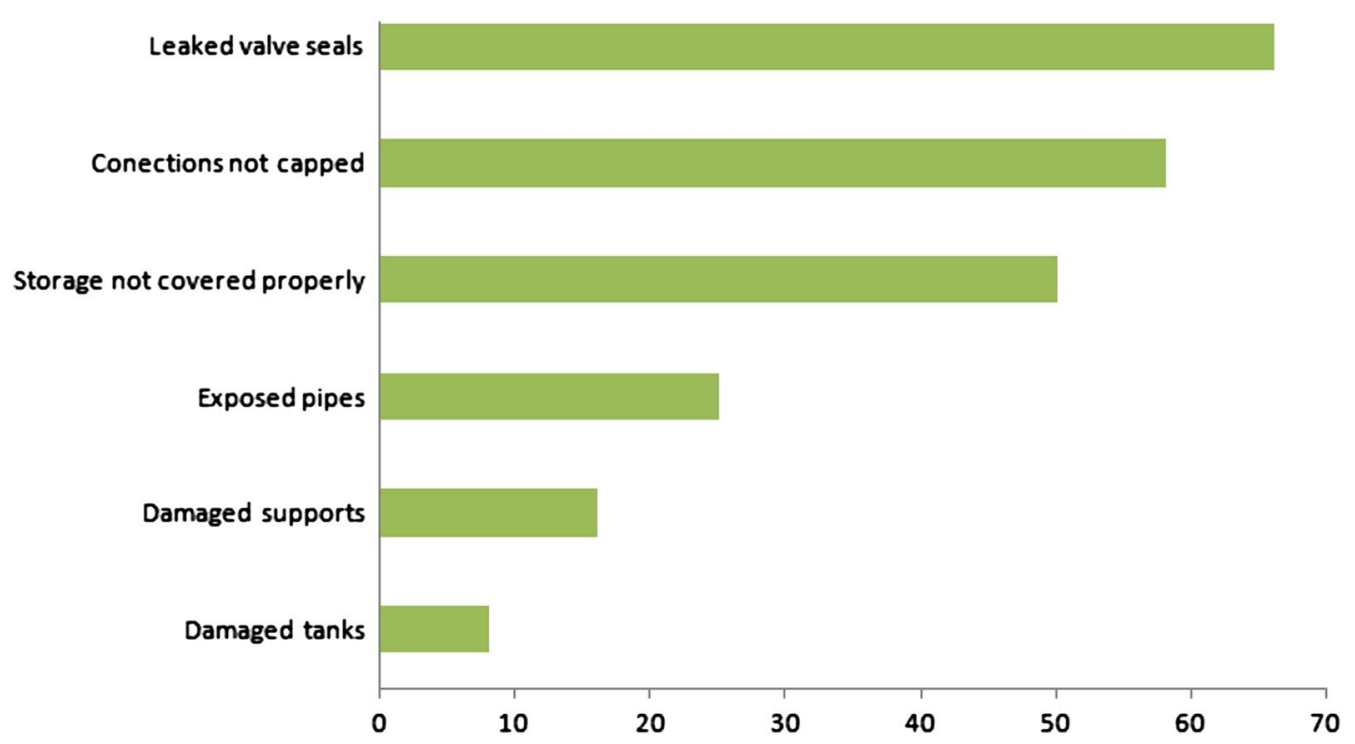

Fig. 2 Hygienic conditions of water storage tanks 
sources found in Wondo Genet were positive for total coliforms (Meride and Ayenew 2016). The study analyzed $1-4 \mathrm{cfu} / 100 \mathrm{ml}$ of total coliforms in the water samples. Total coliforms $(10 \mathrm{cfu} / 100 \mathrm{ml})$ were analyzed in the water samples used for drinking around Jimma Zone (Abera et al. 2011). The type of water, water treatment efficiency, handling practice, site and type of container could aid to the growth of microbes in treated water (Brick et al. 2004). The presence of total coliforms in each water sample collected from protected sources and storage tanks deviated from maximum permissible limits of the WHO. Hence, regular inspection is vital for a provision of microbially free drinking water to communities. According to WHO drinking water guidelines, total coliforms should not be detectable in any water intended for drinking (WHO 2006). Storage tank material and size has also a significance effect on the quality of stored water (Cynthia and Schafer 2012). According to one study, water stored in stainless steel tanks was more contaminated than plastic tanks (Aish 2013). Regarding the size, water stored in the large water storage tanks can be contaminated with total coliforms due to the longer storage times, which may potentially increase the risk of contamination and allow chlorine to volatilize (Graham and VanDerslice 2007).

All of the water samples in the current study were positive for faecal coliforms $(9.33 \mathrm{cfu} / 100 \mathrm{ml})$. Similar to our findings, significantly high counts (up to $250 \mathrm{cfu} / 100 \mathrm{ml}$ ) of faecal coliforms were analyzed in water samples collected from storage tanks found in Ghana (Akuffo et al. 2013). High counts of faecal coliforms (up to $100 \mathrm{cfu} / 100 \mathrm{ml}$ ) were also recorded in household water storage containers in Bahir Dar (Tabor et al. 2011). On the other hand, water samples collected from protected sources were negative for faecal coliforms (Meride and Ayenew 2016). The presence of faecal coliforms in drinking water may affect human health in many ways and it is an indication of the presence of pathogenic bacteria (Mintz et al. 1995). This type of water is not qualified for drinking as $0 \mathrm{cfu} / 100 \mathrm{ml}$ is the recommended guideline. Several factors could be responsible for the presence of faecal coliforms in water storage tanks. For instance, storage tanks cleaning frequency and presence of human or animal faeces can be main driving factors (Cynthia and Schafer 2012). In addition, some of the storage tanks were not covered properly and soil particles and bird faeces could get into the containers that enhance the growth of faecal coliforms. Thus, keeping the water storage tanks clean could improve the microbiological quality of stored water and reduce diarrhoeal and other waterborne diseases in communities (Thompson et al. 2003).

Regarding turbidity of stored water, low turbidity value (2.93 NTU) was recorded from stored water samples. Similarly, low turbidity value (0.98 NTU) was analyzed in water samples collected from Wondo Genet (Meride and Ayenew 2016) and Jimma Zone (Yasin et al. 2015). In all of the findings, the turbidity value falls within the WHO recommended drinking water guideline ( $\leq 5 \mathrm{NTU})$ which might indicate the coagulant doses used in water treatment was efficient to remove suspendered particles found in raw water.

Concerning $\mathrm{pH}$ of water samples, the recorded values ranged from 7.13 to 7.41 where, the value falls within the WHO maximum permissible limits (6.5-8.5). Similar to our findings, Sule et al. (2011) and Yasin et al. (2015) recorded $\mathrm{pH}$ of water samples in the range of 6.53-7.45 and 7.4-8.14 respectively. Basic $\mathrm{pH}$ was analyzed in water storage samples found in Jordan which is reported to be increased upon storage (Ziadat 2005).

Temperature affects the rate of chemical reactions in the water body (Olajire and Imeokparia 2001) and it plays an important role in the survival of microorganisms (Akuffo et al. 2013). The highest recorded temperature in water storage tanks was $23.1{ }^{\circ} \mathrm{C}$ which exceeds the WHO permissible limit of drinking water guidelines $\left(15^{\circ} \mathrm{C}\right)$. This high temperature after storage increased the number of faecal coliforms in storage tanks. It was also reported in one study as high temperature favored the regrowth of bacteria (Muyima and Ngcakani 1998). Storage tank material and color can affect water temperatures in the tanks and placing the tank in a shaded location can reduce temperature meanwhile microbial contamination (Cynthia and Schafer 2012).

\section{Conclusions}

The study revealed that $\mathrm{pH}$, temperature and turbidity of stored tap water in all storage tanks were within the WHO maximum permissible limit of drinking water. However, bacterial loads of total coliforms and faecal coliforms were detected in water samples analyzed before and after storage where increased numbers of coliforms were observed after storing the water. The positive results related to total coliforms and faecal might be due to both leakage and contamination in the distribution system or inadequate treatment. Thus, detail risk assessment should be conducted from treatment to distribution including storage and safe handling of water at the point of use in order to provide complete intervention strategies in tackling waterborne diseases.

\section{Abbreviations \\ APHA: American Public Health Association; CFU: colony forming unit; NTU: nephelometric turbidity unit; WHO: World Health Organization; UNICEF: United Nations of International Children's Emergency Fund.}

\section{Authors' contributions}

All authors have made substantive intellectual contribution to this study in data collection, data analysis, preparation and editing of the manuscript. DC 
conducted the experiments and analyzed the data. MM supervised the experiment, interpreted the data and wrote the draft of manuscript. AB designed the study, edited the manuscript and provided comments and suggestions on the manuscript. All authors read and approved the final manuscript.

\section{Acknowledgements}

The authors would like to thank Jimma University for financial and logistic support.

\section{Competing interests}

The authors declare that they have no competing interests.

Received: 2 May 2016 Accepted: 26 March 2017

Published online: 04 April 2017

\section{References}

Abera S, Zeyinudin A, Kebede B, Deribew A, Ali S, Zemene E (2011) Bacteriological analysis of drinking water sources. Afr J Microbiol Res 5(18):2638-2641

Aish AM (2013) Drinking water quality assessment of the Middle Governorate in the Gaza Strip, Palestine. Water Resour Ind 4:13-20

Akuffo I, Cobbina SJ, Alhassan EH, Nkoom M (2013) Assessment of the quality of water before and after storage in the Nyankpala community of the Tolon-Kumbungu District, Ghana. Int J Sci Technol Res 2(2):2277-8616

Alemu A, Tsegaye W, Golassa L, Abebe Gemeda (2011) Urban malaria and associated risk factors in Jimma town, south-west Ethiopia. Malar J $10: 173$

APHA (2005) Standard methods for examination of water and wastewater, 21st edn. American Public Health Association, Washington

AWWA (2007) Advanced the science of water: Awwa RF and distribution system water quality. http://eclass.duth.gr/modules/document/file.php. Accessed Mar 2014

Bain R, Cronk R, Wright J, Yang H, Slaymaker T, Bartram J (2014) Fecal contamination of drinking-water in low- and middle-income countries: a systematic review and meta-analysis. PLoS Med 11(5):23

Brick T, Primrose B, Chandrasekhar R, Roy S, Muliyil J, Kang G (2004) Water contamination in urban south India: household storage practices and their implications for water safety and enteric infections. Int J Hyg Environ Health 207(5):473-480

Cheesbrough M (2006) Medical laboratory manual for tropical countries. Cambridge University Press, London

Cynthia A, Schafer Mihelcic JR (2012) Effect of storage tank material and maintenance on household water quality. J Am Water Works Assoc 10(49):49-50
Duer MJ (2006) The science of mixing and improving water quality in water storage tanks. http://waterworld.com/content/ww/en/whitepapers/. Accessed Mar 2015

Fard RF, Bidhendi GN, Azimi AA (2012) Biosorption of nickel from batch reactor using the powder of waste activated sludge. Res J Environ Sci 5:461-470

Graham JP, VanDerslice J (2007) The effectiveness of large household water storage tanks for protecting the quality of drinking water. J Water Health 5(2):307-313

Meride Y, Ayenew B (2016) Drinking water quality assessment and its effects on residents health in Wondo genet campus, Ethiopia. Environ Syst Res $5: 1$

Mintz ED, Reiff FM, Tauxe RV (1995) Safe water treatment and storage in the home. A practical new strategy to prevent water-borne disease. J Am Med Assoc 273:948-953

Muyima NYO, Ngcakani F (1998) Indicator bacteria and re-growth potential of the drinking water in Alice, Eastern Cape. WATER SA-PRETORIA 24(1):29-34

Olajire AA, Imeokparia FE (2001) Water quality assessment of Osun River: studies on inorganic nutrients. Environ Monit Assess 69:17-22

Sule IO, Agbabiaka TO, Akomolafe AV (2011) Bacteriological quality of water stored exteriorly in storage tanks. Res J Environ Sci 5(6):603-610

Tabor M, Kibret M, Abera B (2011) Bacteriological and physicochemical quality of drinking water and hygiene-sanitation practices of the consumers in Bahir Dar city, Ethiopia. Ethiop J Health Sci 21(1):19-26

Thompson T, Sobsey M, Bartram J (2003) Providing clean water, keeping water clean: an integrated approach. Int J Environ Heal R 13:89-94

UNICEF/WHO (2015) Progress on sanitation and drinking water 2015 update and MDG assessment. World Health Organization, Geneva

WHO (2006) Guideline for drinking-water quality: incorporating first addendum recommendations, 3rd edn. World Health Organization, Geneva

WHO (2014) Water-related diseases. http://www.who.int/water_sanitation_ health/diseases/en/. Accessed Feb 2016

WHO (2015) Drinking-water fact sheet N³91. http://www.who.int/mediacentre/factsheets/fs391/en/. Accessed Feb 2016

WWAP (2012) Statics on water use. World Water assessment programme. http://www.unesco.org/new/en/naturalsciences/environment/water/ wwap. Accessed Feb 2016

Yasin M, Ketema T, Bacha K (2015) Physico-chemical and bacteriological quality of drinking water of different sources, Jimma zone, Southwest Ethiopia. BMC Res Notes 8:541

Zaqoot HA, Hamada M, El-Tabash MA (2016) Investigation of drinking water quality in the kindergartens of Gaza Strip Governorates. J Tethys 4(2):88-99

Ziadat AH (2005) Impact of storage tanks on drinking water quality in Al-Karak province Jordan. J Appl Sci 5(4):634-638

\section{Submit your manuscript to a SpringerOpen ${ }^{\odot}$ journal and benefit from:}

- Convenient online submission

- Rigorous peer review

- Immediate publication on acceptance

- Open access: articles freely available online

- High visibility within the field

- Retaining the copyright to your article

Submit your next manuscript at springeropen.com 